\title{
UJI DAYA HAMBAT EKSTRAK ETANOL DAUN MAHKOTA DEWA (Phaleria macrocarpa Boerl.,) TERHADAP BAKTERI Staphylococcus aureus
}

\author{
Susi Novaryatiin ${ }^{1}$, Nurul Chusna ${ }^{1}$, Desti Amelia² \\ 1'Dosen Pengajar Program Studi DIII Farmasi, Fakultas IImu Kesehatan, Universitas \\ Muhammadiyah Palangkaraya \\ ${ }^{2}$ Mahasiswa Program Studi DIII Farmasi, Fakultas IImu Kesehatan, Universitas \\ Muhammadiyah Palangkaraya \\ e-mail : susi novaryatiin@yahoo.com
}

\begin{abstract}
ABSTRAK
Pemanfaatan bahan alam sebagai obat tradisional di Indonesia akhir-akhir ini meningkat, bahkan beberapa bahan alam telah diproduksi secara fabrikasi dalam skala besar. Penggunaan obat tradisional dinilai memiliki efek samping yang lebih kecil dibandingkan dengan obat yang berasal dari bahan kimia, disamping itu harganya lebih terjangkau. Selain itu keuntungan lain penggunaan obat tradisional adalah bahan bakunya mudah diperoleh dan harganya yang relatif murah.

Tanaman Mahkota Dewa merupakan tanaman yang sering ditemui dan mudah didapat di Indonesia. Sejak dahulu, khasiat Mahkota dewa sebagai tanaman obat sering digunakan dalam masyarakat terutama daunnya. Daun mahkota dewa diyakini mengandung zat kimia alamiah yang rendah efek samping dibandingkan dengan obat-obatan farmasetik lainnya yang menjadikan daun Mahkota Dewa sebagai pilihan masyarakat dalam pengobatan tradisional. Daun Mahkota Dewa memiliki khasiat sebagai obat analgesik, antibakteri, dan antihistamin. Penelitian ini dilakukan untuk mengetahui kemampuan daya hambat ekstrak etanol daun Mahkota Dewa pada bakteri Staphylococcus aureus berdasarkan konsentrasi ekstraknya.

Penelitian ini dilakukan menggunakan metode Kirby-Bauer yaitu metode difusi dengan menggunakan kertas cakram (disc). Proses ekstraksi dilakukan dengan metode perkolasi dengan pelarut etanol $96 \%$. Pengujian dilakukan menggunakan 4 variasi konsentrasi dengan 3 kali pengulangan. Hasil penelitian menunjukkan bahwa ekstrak etanol daun Mahkota Dewa mampu menghambat pertumbuhan bakteri Staphylococcus aureuspada konsentrasi yang diujikan 1\%, 5\%, 10\%, dan $15 \%$ dengan zona hambat berturut-turut $8,3 \pm 1,1 \mathrm{~mm} ; 9,8 \pm 1,9 \mathrm{~mm} ; 11,6 \pm 1,2 \mathrm{~mm}$; dan $13,1 \pm 1,8 \mathrm{~mm}$.
\end{abstract}

Kata Kunci: Uji daya hambat, ekstrak etanol daun Mahkota Dewa, Staphylococcus aureus

\section{ABSTRACT}

The utilization of natural materials as a traditional medicine in Indonesia has recently increased, even some natural materials have been manufactured in fabrication on a large scale. The use of traditional medicine is considered to have less side effects compared with chemicals, besides that the 
price is more affordable. Besides other advantages of traditional medicine is the raw material is easy to obtain and the price is relatively cheap.

Mahkota Dewa plant is often found and easily obtainable in Indonesia. Since the first, the efficacy of Mahkota Dewa as a medicinal plant is often used in society, especially leaves. Mahkota Dewa is believed to contain a low natural chemical side-effects compared to other pharmaceutical drugs that make the Mahkota Dewa leavesas the people's choice in traditional medicine. Mahkota Dewa has efficacy as an analgesic, antibacterial, and antihistamine drug. This study was aimedto determine the ability of inhibitory power of ethanolic extract of Mahkota Dewa leaves on Staphylococcus aureus bacteria based on the concentration of the extract.

This research was conducted using Kirby-Bauer method that is diffusion method by using disc paper. The extraction process was carried out by percolation method with $96 \%$ ethanol solvent. The test was performed using 4 concentration variations with 3 repetitions. The results showed that ethanolic extract of Mahkota Dewa leaves was able to inhibit the growth of Staphylococcus aureus bacteria at tested concentrations of $1 \%, 5 \%, 10 \%$, and $15 \%$ with inhibition zone were $8.3 \pm 1.1 \mathrm{~mm} ; 9.8 \pm 1.9 \mathrm{~mm} ; 11.6 \pm 1.2 \mathrm{~mm}$; and $13.1 \pm 1.8 \mathrm{~mm}$, respectively.

Keywords: The inhibitory test, ethanolic extract of Mahkota Dewa leaves, Staphylococcus aureus

\section{PENDAHULUAN}

Obat tradisional di Indonesia sangat besar peranannya dalam pelayanan kesehatan masyarakat di Indonesia, sehingga obat tradisional sangat berpotensi untuk dikembangkan. Indonesia kaya akan tanaman obat-obatan, yang mana masih belum dimanfaatkan secara optimal untuk kesehatan. Obat tradisional merupakan warisan budaya bangsa yang perlu terus dilestarikan dan dikembangkan untuk menunjang pembangunan kesehatan sekaligus untuk meningkatkan perekonomian rakyat[1].

Pemanfaatan bahan alam sebagai obat tradisional di Indonesia akhir-akhir ini meningkat, bahkan beberapa bahan alam telah diproduksi secara fabrikasi dalam skala besar. Penggunaan obat tradisional dinilai memiliki efek samping yang lebih kecil dibandingkan dengan obat yang berasal dari bahan kimia, disamping itu harganya lebih terjangkau. Selain itu keuntungan lain penggunaan obat tradisional adalah bahan bakunya mudah diperoleh dan harganya yang relatif murah [2]

Tanaman obat adalah tanaman yang memiliki khasiat obat dan digunakan sebagai obat dalam peyembuhan maupun pencegahan penyakit. Pengertian berkhasiat obat adalah mengandung zat aktif yang berfungsi mengobati penyakit tertentu atau jika tidak mengandung zat aktif 
Uji Daya Hambat Ekstrak Etanol Daun Mahkota Dewa (Phaleria macrocarpa Boerl.) Terhadap Bakteri Staphylococcus aureus

tertentu tapi mengandung efek resultan atau sinergi dari berbagai zat yang berfungsi mengobati [3]

Mahkota Dewa (Phaleria macrocarpa Boerl.,) merupakan tanaman asli Indonesia. Mahkota Dewa populer karena kemampuannya dalam mengobati berbagai macam penyakit yaitu kanker, tumor, diabetes melitus, hipertensi, hepatitis, rematik, asam urat, penyakit kulit, gangguan ginjal, alergi, asma, ambeien, stroke, dan migrain (Katrin et al., 2011).Hampir semua bagian dari tanaman Mahkota Dewa, meliputi buah, biji, batang dan daun, dapat digunakan sebagai obat [4] Kandungan kimia yang dimiliki tanaman marga Phaleria pada umumnya memiliki aktivitas antimikroba. Aktivitas ini berkaitan dengan toksisitas (kandungan racun) tanaman yang cukup tinggi sebagai salah satu bentuk dan mekanisme pertahanan diri. Dari sejumlah pengalaman eksperimental terbukti pula bahwa sebagian besar tanaman yang memiliki aktivitas antimikroba pada umumnya juga menunjukkan potensi sebagai suatu antikanker karena toksitas yang dimilikinya tersebut dapat pula bekerja terhadap fase tertentu dari siklus sel tumor.

Daun Mahkota Dewa diyakini mengandung zat kimia alamiah yang rendah efek samping dibandingkan dengan obat-obatan farmasetik lainnya yang menjadikan daun Mahkota Dewa sebagai pilihan masyarakat dalam pengobatan tradisional [5]. Daun Mahkota Dewa berkhasiat sebagai obat analgesik, antibakteri, dan antihistamin [6]Hasil penelitian menunjukkan bahwa infusa daun Mahkota Dewa memiliki daya antibakteri terhadap Staphylococcus aureus dengan KHM 3,125 gram \% dan KBM 6,25 gram\%[7].

Berdasarkan latar belakang di atas maka peneliti tertarik untuk melakukan penelitian tentang "Uji Daya Hambat Ekstrak Etanol Daun Mahkota Dewa (Phaleria macrocarpa Boerl.,) Terhadap Bakteri Staphylococcus aureus".

Penelitian ini bertujuan untuk mengetahui kemampuan daya hambat ekstrak etanol daun Mahkota Dewa pada bakteri Staphylococcus aureus berdasarkan konsentrasi ekstraknya.

\section{METODE PENELITIAN}

Rancangan Penelitian

Penelitian ini dilakukan di Laboratorium Farmakognosi dan Laboratorium Mikrobiologi Fakultas IImu Kesehatan Universitas Muhammadiyah Palangkaraya. Penelitian dilaksanakan selama 4 (empat) bulan. Kegiatan penelitian yang dilakukan adalah pengambilan 
sampel, pembuatan simplisia, pembuatan ekstrak, penanaman bakteri, dan uji daya hambat.

\section{Sampel Penelitian}

Sampel penelitianadalah tanaman Mahkota Dewa (Phaleria macrocarpa Boerl.) yang tumbuh di sekitar Jl. G.Obos XII Kota Palangka Raya Provinsi Kalimantan Tengah. Tanaman Mahkota Dewa yang diteliti adalah bagian daun yang segar.

\section{Pembuatan Simplisia}

Dilakukan sortasi basah pada daun Mahkota Dewa, lalu daun dipotong-potong, dan dijemur. Setelah kering simplisia disortasi kembali dan dihaluskan hingga menjadi serbuk [8].

\section{Pembuatan Ekstrak}

Pembuatan ekstrak daun Mahkota Dewa dilakukan dengan metode perkolasi. Keuntungan dari metode ini yaitu mudah, sederhana, dan peluang resiko pengotor sangat kecil karena digunakan pelarut yang selalu baru (exhaustive extraction) pada temperatur ruangan. Penggunaan pelarut etanol 96\% karena etanol merupakan pelarut universal yang mampu melarutkan hampir seluruh jenis metabolit sekunder yang terkandung dan tidak bersifat racun serta aman untuk digunakan [9]. Dilakukan penimbangan ekstrak kental yang didapat. Ekstrak yang diperoleh lalu dibuat dalam berbagai variasi konsentrasi yaitu $1 \%, 5 \%$, $10 \%$, dan $15 \%$.

\section{Penanaman Bakteri}

Bakteri Staphylococcus aureus ditanam pada media Brain Heart Infusion (BHI) pada suhu $37 \stackrel{\circ}{ } \mathrm{C}$ selama 24 jam, lalu ditumbuhkan pada media Blood Agar Plate (BAP) pada suhu $37^{\circ} \mathrm{C}$ selama 24 jam.

\section{Uji Daya Hambat}

Uji daya hambat dilakukan menggunakan metode difusi (Kirby-Bauer), dimana disc direndam dalam variasi konsentrasi ekstrak etanol daun Mahkota Dewa 1\%, 5\%, 10\%, dan 15\%. Standar McFarland 0,5 disiapkan, dan $10 \mathrm{ml}$ dimasukkan ke dalam tabung steril. Suspensi bakteri dibuat dengan mengambil koloni bakteri, diencerkan dalam $\mathrm{NaCl}$ steril, dan kekeruhan disesuaikan dengan standar McFarland 0,5. Suspensi bakteri diambil dan di-streak pada media Mueller Hinton Agar (MHA) dengan menggunakan lidi kapas steril. Kemudian semua disc yang telah direndam dalam ekstrak etanol daun Mahkota Dewa ditanam pada media MHA. Antibiotik tetrasiklin digunakan sebagai kontrol positif dengan variasi konsentrasi $1 \%, 5 \%$, 10\%, dan $15 \%$. Disc yang telah direndam dalam tetrasiklin juga ditanam di media MHA. Inkubasi dilakukan pada suhu $37{ }^{\circ} \mathrm{C}$ selama 24 jam. Zona hambat diukur menggunakan jangka sorong. Dilakukan pengulangan sebanyak tiga kali (triplo) untuk masing-masing ekstrak dan kontrol positif.

\section{Teknik Analisis Data}


Analisis data dilakukan dengan menghitung zona hambat ekstrak etanol daun Mahkota Dewa terhadap bakteri Staphylococcus aureus. Hasil disajikan dalam bentuk tabel dan foto,disertai dengan perbandingan antara hasil yang diperoleh dengan standar yang telah ditetapkan oleh CLSI [10].

HASIL DAN PEMBAHASAN

\section{Perhitungan Rendemen Ekstrak}

$$
\begin{aligned}
\text { Rendemen } & =\frac{\text { Berat ekstrak kental }}{\text { Berat simplisia }} \times 100 \% \\
& =\frac{62,5816 \text { gram }}{300 \text { gram }} \times 100 \% \\
& =0,2086 \times 100 \% \\
& =20,86 \%
\end{aligned}
$$

Jumlah total ekstrak kental yang diperoleh adalah sebanyak $62,5816 \mathrm{gr}$ dan rendemen yang didapatkan adalah 20,86 \% (Gambar 1).

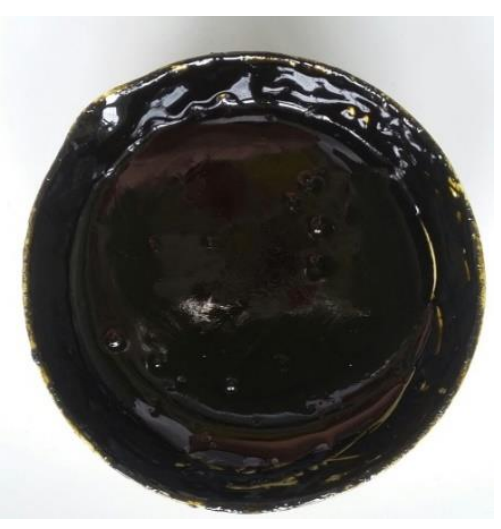

Gambar 1. Ekstrak kental daun Mahkota Dewa

\section{Uji Daya Hambat}

Hasil uji daya hambat ekstrak etanol

daun Mahkota Dewa dapat dilihat pada Tabel

\begin{tabular}{|c|c|c|c|c|c|c|}
\hline \multirow[t]{2}{*}{ Uji } & \multirow[t]{2}{*}{$\begin{array}{c}\text { Konsentrasi } \\
(\%)\end{array}$} & \multicolumn{3}{|c|}{$\begin{array}{l}\text { Zona Hambat } \\
\text { (mm) }\end{array}$} & \multirow[t]{2}{*}{$\begin{array}{c}\text { Rata-Rata Zona } \\
\text { Hambat } \pm \text { SD }(\mathrm{mm})\end{array}$} & \multirow[t]{2}{*}{$\begin{array}{c}\text { Interpretasi } \\
\text { Daya Hambat }\end{array}$} \\
\hline & & I & II & III & & \\
\hline \multirow{4}{*}{$\begin{array}{c}\text { Kontrol } \\
\text { Positif } \\
\text { Tetrasiklin }\end{array}$} & $1 \%$ & 12,2 & 12,1 & 11,2 & $11,8 \pm 0,6$ & Resistant \\
\hline & $5 \%$ & 27,5 & 19,5 & 25,9 & $24,3 \pm 4,2$ & Susceptible \\
\hline & $10 \%$ & 30,9 & 32,6 & 30 & $31,2 \pm 1,3$ & Susceptible \\
\hline & $15 \%$ & 32,6 & 31,9 & 32,2 & $32,2 \pm 0,4$ & Susceptible \\
\hline
\end{tabular}

1 berikut ini.

Tabel 1.Hasil Pengukuran Zona Hambat Ekstrak Etanol Daun Mahkota Dewa Dibandingkan dengan CLSI 


\begin{tabular}{ccccccc}
\hline Ekstrak & $1 \%$ & 7,2 & 9,3 & 8,3 & $8,3 \pm 1,1$ & Resistant \\
\cline { 2 - 7 } Etanol Daun & $5 \%$ & 12 & 8,2 & 9,3 & $9,8 \pm 1,9$ & Resistant \\
\cline { 2 - 7 } Mahkota & $10 \%$ & 12,3 & 10,2 & 12,2 & $11,6 \pm 1,2$ & Resistant \\
\cline { 2 - 7 } Dewa & $15 \%$ & 14,1 & 14,2 & 11,1 & $13,1 \pm 1,8$ & Resistant \\
\hline
\end{tabular}

Keterangan :

* Interpretasi Daya Hambat (CLSI, 2013),

$$
\begin{aligned}
& \leq 14 \mathrm{~mm}=\text { Resistant } \\
& 15-18 \mathrm{~mm}=\text { Intermediate } \\
& \geq 19 \mathrm{~mm}=\text { Susceptible }
\end{aligned}
$$

Pada penelitian ini tetrasiklin 1\%, 5\%, 10\%, dan $15 \%$ terhadap digunakan sebagai kontrol positif. Antibiotik Staphylococcus aureus secara berturut-turut ini merupakan antibiotik dengan spektrum

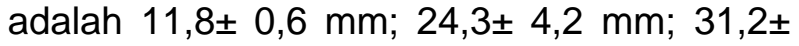
luas dan digunakan untuk mengobati infeksi 1,3 mm; dan 32,2 \pm 0,4 mm (Tabel 1, Gambar yang disebabkan oleh bakteri gram negatif 2). Berdasarkan CLSI, zona hambat dan gram positif [12]. Salah satu bakteri yang tetrasiklin yang diujikan pada konsentrasi $1 \%$ dapat dihambat oleh tetrasiklin adalah dikategorikan resistant, konsentrasi 5\%, 10\% Staphylococcus aureus. Zona hambat yang dan $15 \%$ dikategorikan susceptible.

dihasilkan oleh tetrasiklin pada konsentrasi

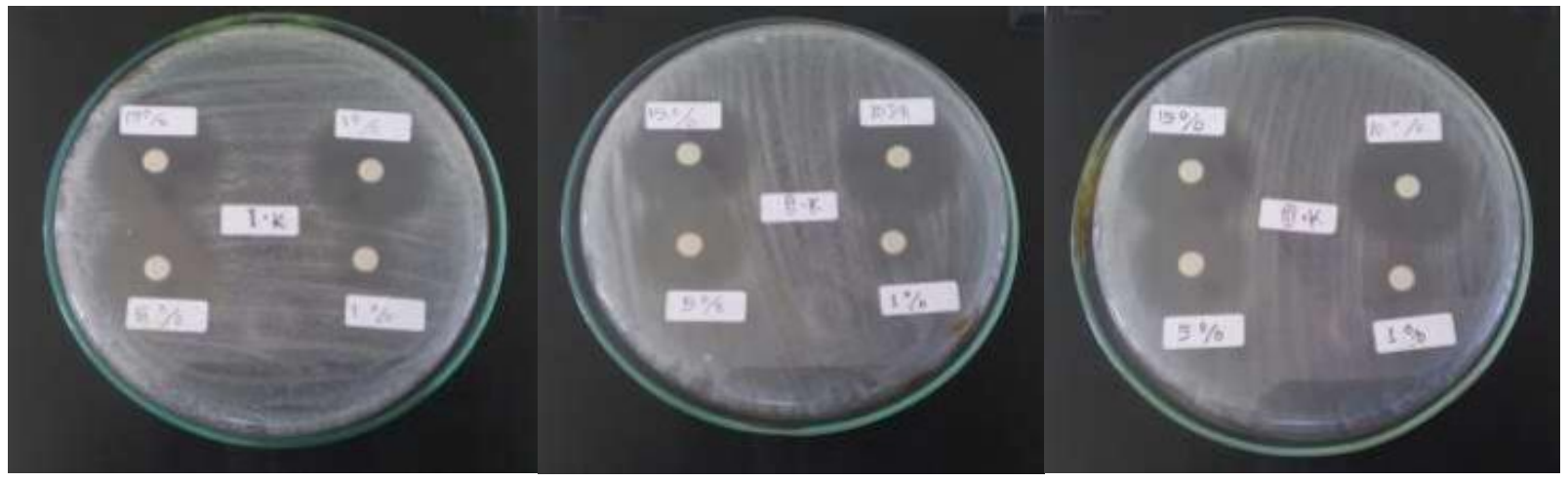

Gambar 2. Hasil pengamatan uji daya hambat antibiotik tetrasiklin terhadap bakteri Staphylococcus aureus

Uji daya hambat ekstrak etanol daun Mahkota Dewa dilakukan sebanyak tiga kali pengulangan, menunjukkan adanya zona hambat yang bervariasi (Gambar 3). Zona hambat pada konsentrasi $1 \%, 5 \%, 10 \%$, dan $15 \%$ secara berturut-turut sebesar $8,3 \pm 1,1$

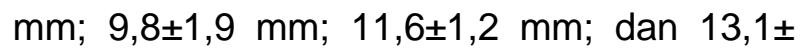
1,8 mm (Tabel 1). 
Uji Daya Hambat Ekstrak Etanol Daun Mahkota Dewa (Phaleria macrocarpa Boerl.) Terhadap Bakteri Staphylococcus aureus

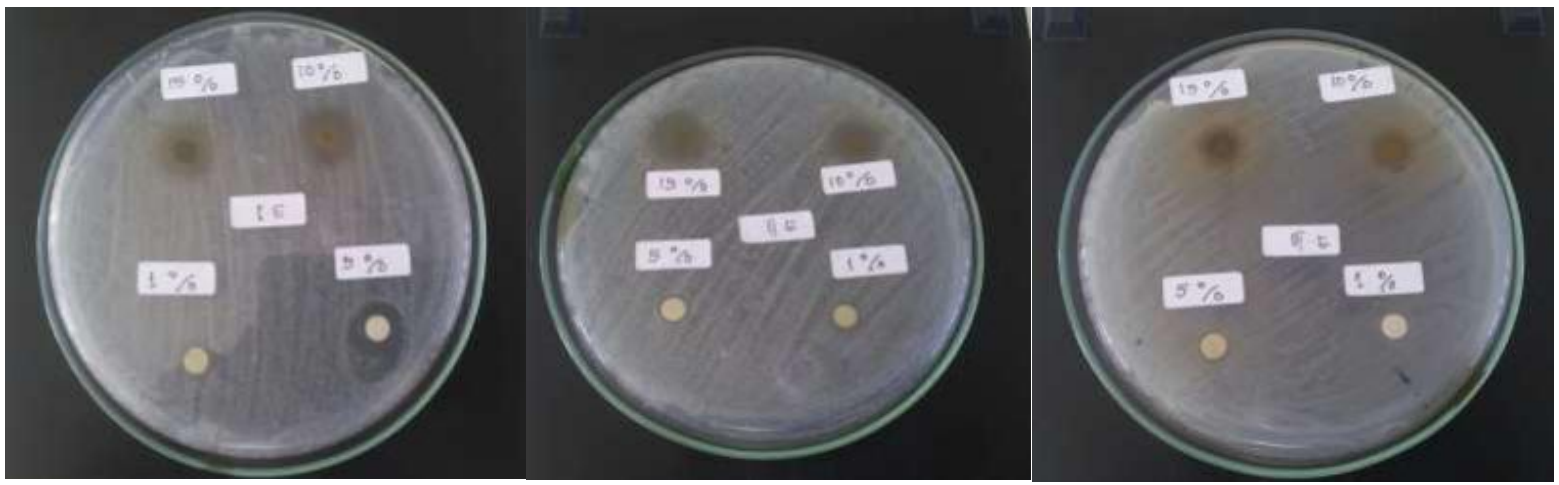

Gambar 3. Hasil pengamatan uji daya hambat ekstrak etanol daun Mahkota Dewa terhadap bakteri Staphylococcus aureus

Semakin tinggi konsentrasi ekstrak etanol daun Mahkota dewa maka semakin besar zona hambat yang dihasilkan. Kandungan senyawa di dalam daun Mahkota dewa yang dapat menghambat pertumbuhan Staphylococcus aureus salah satunya yaitu flavonoid.

Flavonoid merupakan senyawa fenol yang bekerja dengan cara mendenaturasi protein yang dapat meyebabkan aktivitas metabolisme sel dikatalis oleh suatu enzim. Karena flavonoid memiliki kemampuan untuk membentuk kompleks dengan protein ekstraseluler terlarut dan dengan dinding sel, sehingga mikroorganisme tidak dapat melekat dan menginvasi sel [13]. Flavonoid bekerja dengan menghambat pembelahan atau proliferasi sel bakteri. Senyawa ini mengikat protein pada mikrotubulus dalam sel dan mengganggu fungsi mitosis sehingga menimbulkan penghambatan pertumbuhan bakteri. Senyawa fenol sebagai antibakteri adalah dengan mendenaturasi ikatan protein pada membran sel sehingga membran sel lisis dan memungkinkan fenol menembus ke dalam sitoplasma yang menyebabkan bakteri tidak berkembang [14].

Jika dibandingkan dengan standar CLSI, maka zona hambat yang dihasilkan oleh ekstrak etanol daun Mahkota Dewa pada semua konsentrasi yang digunakan masuk ke dalam kategori resistant. Namun, hasil penelitian ini juga menunjukkan bahwa pada konsentrasi ekstrak daun Mahkota Dewa yang semakin tinggi diperoleh zona hambat bakteri yang semakin besar.

\section{KESIMPULAN}

Kesimpulan yang didapat dari penelitian ini yaitu ekstrak etanol daun Mahkota Dewa mampu menghambat pertumbuhan bakteri Staphylococcus aureuspada konsentrasi yang diujikan $1 \%$, $5 \%, 10 \%$, dan $15 \%$ dengan zona hambat 
berturut-turut $8,3 \pm 1,1 \mathrm{~mm} ; \quad 9,8 \pm 1,9 \mathrm{~mm}$; $11,6 \pm 1,2 \mathrm{~mm}$; dan 13,1 $\pm 1,8 \mathrm{~mm}$

\section{DAFTAR PUSTAKA}

1. Notoatmodjo, S. 2007. Promosi Kesehatandan IImu Perilaku. Jakarta :Rineka Cipta.

2. Putri, Z.F. 2010. Uji Aktivitas Antibakteri Ekstrak Etanol Daun Sirih (Piper betle L.) Terhadap Propionibacterium acne dan Staphylococcus aureus multiresisten.Skripsi. Surakarta: Fakultas Farmasi Universitas MuhammadiyahClinical Laboratory Standart Institute. 2013. Performance Standart for Antimicrobial Susceptibility Testing; Twentieth Information Supplement. USA.

3. Siajabat, G.2012. Informasi Peredaran Tumbuhan Obat Hutan di Tanah Karo (Studi Kasus Pasar Tradisional Kabanjahedan Pasar Tradisional Berastagi). Skripsi. Medan: Fakultas Fariza I. N., Fadzureena, J., Zunoliza, A., Chuah, A.L., Pin, K.Y., Adawiah, I. 2012.Anti-Inflammatory Activity of the Major Compound from Methanol Extract of Phaleria macrocarpa Leaves. Journal of Applied Sciences, 12(11): 1195-1198.

4. Katrin E., Selvie, Winarno H. 2011. Chomatogram Profiles and Cytotoxic Activity of Irradiated Mahkota Dewa (Phaleria Macrocarpa (Scheff.) Boerl)leaves. Atom Indonesia, 37(1): 17-23.

5. Fariza I. N., Fadzureena, J., Zunoliza, A., Chuah, A.L., Pin, K.Y., Adawiah, I. 2012.Anti-Inflammatory Activity of the Major Compound from Methanol Extract of Phaleria macrocarpa
Leaves. Journal of Applied Sciences, 12(11): 1195-1198.

6. Dalimartha, S. 2005. Tanaman obat di lingkungan sekitar. Jakarta: Puspa Swara.

7. Harmanto, N. 2006. Ibu Sehat dan Cantik dengan Herbal. Jakarta: PT. Elex Media Komputindo.

8. Suryani, L. dan Strepriyani, S. 2007. Daya Antibakteri Infusa Daun Mahkota Dewa (Phaleria macrocarpa) Terhadap Staphylococcus aureus dan Eschericia coli. Mutiara Medika, 7(1): 23-28.

9. Departemen Kesehatan Republik Indonesia.1995. Materia Medika Indonesia Jilid IV. Jakarta.

10. Harborne, J.B. 1987. Metode Fitokimia Penuntun Cara Modern Menganalisa Tumbuhan. Penerjemah: Kosasih Padmawinata dan Iwang Soediro. Terbitan Kedua. Bandung: Penerbit ITB.

11. Clinical Laboratory Standart Institute. 2013.Performance Standart for Antimicrobial Susceptibility Testing; Twentieth Information Supplement. USA.

12. Irianto, K. 2013. Mikrobiologi Medis. Bandung: Penerbit Alfabeta.

13. Susanti, N. 2016. Aktivitas Antimikroba Ekstrak Rimpang Jeringau (Acorus calamus) Terhadap Pertumbuhan Candida albicans. Jurnal Biodjati, 1(1): 55-58.

14. Haerazi A., Dwi S.D.J., Yayuk, A. 2016. Uji Aktivitas Antibakteri Ekstrak Kencur (Kaempferia galangal L.) Terhadap Pertumbuhan Bakteri Staphylococcus aureus dan Streptococcus Viridans. Jurnal IImiah Pendidikan Biologi Bioscientist, 2(1):75-82. 